\title{
Observations on Artemisia in Nevada ${ }^{1}$
}

\section{JAMES R. BRUNNER}

Las Vegas, Nevada.

\section{Highlight}

Seven years of study of the various species and forms of sagebrush (Artemisia spp.) found in Nevada reveal that although there are about 28 different sagebrushes, there are only 4 of grazing importance. Thin-layer chromatography was used to identify the sagebrushes and a system of identification using leaf shape has been devised.

It is usually conceded that sagebrush species (Artemisia spp.) are most difficult to identify. Part of the problem has been a lack of descriptions of the Great Basin sagebrushes. Another part of the problem is that most persons have considered sagebrush as a worthless weed.

This paper will attempt to describe the common sagebrush plants of Nevada. Four of the sagebrushes arc highly palatable to wildlife and/or livestock. Sagebrushes vary in their ability to volunteer after wildfire and in their resistance to 2,4-D spray. Wallmo ${ }^{2}$ in Colorado and Plummer ${ }^{3}$ in Utah have found decided preference by deer for certain sagebrushes.

\section{Area and Methods}

Most of the study has been concentrated in northern and central

\footnotetext{
${ }^{1}$ Received April 19, 1971.

2 Personal Communication, O. C. Wallmo, 1969.

${ }^{3}$ Personal Communication, Perry Plum. mer.
}

Nevada. Collecting trips to Idaho, Wyoming, and Utah were made to extend the scope of the study. It is quite clear, however, that the presence of the Quaternary lakes (Russell, 1885) and possibly the Pleistocene lakes in Nevada have causcd a specialization of the plants. Therefore, any attempt to extend this study beyond the area influenced by these lakes was abandoned.

Methods consisted of voluminous collection of every sagebrush that appeared somewhat different phenologically. Use was made of Beetle's (1960) publication supplemented by identification of samples by Drs. A. A. Beetle and $\mathrm{Al}$ Winward. Thin-layer chromatograms were run on each samplc to note any differences in chemical composition. When a species was positively identified, thin-layer chromatography was used to record the chemical signature of that species. Unknown plants were chromatogrammed to aid in their identification. Gradually, order began to appear out of chaos.
Young's (1965) method of thinlayer chromatography was modified to fit my situation. Research specialities operating manual and Randerath (1966) were consulted and some ideas of Holbo and Mozingo (1965) were incorporated.

Sagebrush leaves were gathered from the plants, taking all leaves for a sample from a single plant. Often, the adjacent plant is a different form of sagebrush. It was found that sagebrush grows vegetative leaves early, usually in midFebruary, and then at seeding time the plants grow a set of large leaves in addition to the vegetative leaves. Winward and Tisdale (1969) call these large leaves, "ephemeral" leaves since they turn brown and fall after seed maturity. The vegetative leaves remain functional until killed by drought or frost. The ephemeral leaves cause an extra flare on the chromatogram; therefore Winward and Tisdale (1969) and Hanks (1971) use only vegetative leaves in their work. It is much preferred to follow this procedure.

Two grams of the vegetative leaves are placed in a $35 \mathrm{~mm}$ film can or other suitable air-tight container. Five $\mathrm{ml}$ of reagent alcohol (Baker 9400) are added and the material is left to steep for 24 hours at room temperature. If the leaves are very dry, 7 to $8 \mathrm{ml}$ of alcohol will be needed to produce about 5 cc of solution. See Winward and 

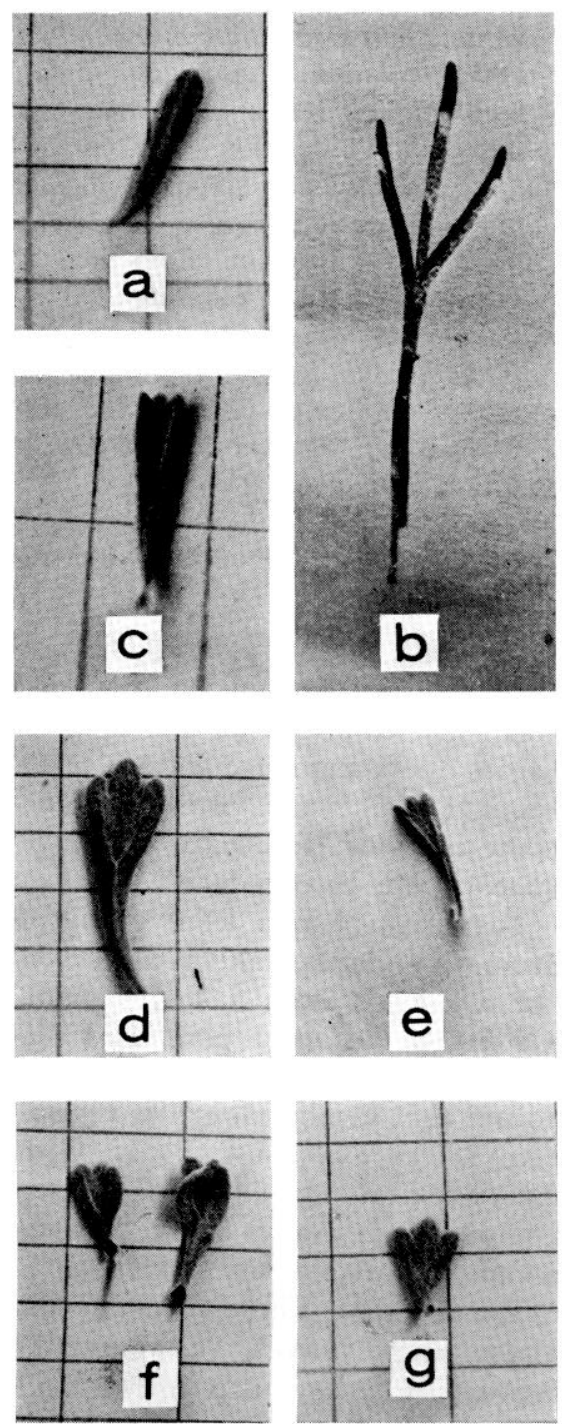

Fig. 1. Type leaf shapes (Not to scale).
Tisdale (1969) for a quick identification method which is very satisfactory in many cases. If you are sure a plant is either Artemisia nova or $A$. arbuscula, for instance, a quick look at the solution color under ultra-violet light makes further steps unnecessary.

After the solution has steeped, place 3 drops on a corner of a chromatogram sheet (Kodak "Chromagram” 6061, Silica gel, without fluorescent indicator). Start the drop about $1^{\prime \prime}$ in from the edges. Dry each drop before placing another. If too much solution is placed on the sheet, the chromatogram will be "over-loaded" and not all of the solution will run up the sheet; certain colors may be obscured. Use about 2 cc.

While the last drop is drying, place in a glass jar such as a standard $9 \times 5 \times 9$ inch chromatogram jar) equal amounts $(35 \mathrm{ml})$ of distilled water, 1-Butanol (Baker 9054), and acetone (Baker 9006). Add about $5 \mathrm{ml}$ of ammonium hydroxide (B\&A 1923) for fluorescence. Place the chromatogram sheet in the jar in a stainless steel rack (inclined to about $70^{\circ}$ ) with the solution spot down. The bottom of the sheet should be in the eleutant (chemical mix) 2 to $3 \mathrm{~mm}$, but the spot should not be in the eleutant. Cover the jar. The eleutant will run up the sheet by capillarity carrying the various poly-phenols (Holbo and Mozingo, 1965) of the solution. Since the various polyphenols are soluable to certain degrees in the various chemicals of the eleutant, and the chemicals of the eleutant "run" up the sheet at different rates, the poly-phenols are separated and spread. Do not work in direct sunlight.

When the run has reached $10 \mathrm{~cm}$ (4 inches) after $1 \frac{1 / 2}{2}$ to 2 hours, remove the sheet and read it wet in a darkened room under long-wave ultra-violet light $(580 \AA)$. The run under conditions of moderate temperature is much faster than at cool temperatures. If very low humidity prevails, the colors apparently require more time to become apparent.

Various bright colors will be noted. The red flare at the head of the run is chlorophyll and is not used in identification (Young, 1965). It is an indication, by its brightness, of the condition of the leaf sample -if dull, beware. The color following the chlorophyll will generally indicate the species of Artemisia. This first flare is called the primary flare. Subsequent colors will indicate the sub-species. As the chromatogram dries, the colors will fade or change. To preserve the chromatogram, one may photograph the fresh chromatogram. I use Kodachrome II film, 2 -B filter, $1 / 5$ sec. @2.8. This filter is best for blues and greens. Use a K-2 filter, 1 sec. @2.0 if the yellows are most important.

\section{Plant Identification}

\section{Vegetative or Field Identification}

The field identification of sagebrush requires the same degree of attention to detail as when one keys out a small forb or grass. Identification is usually possible by examining the shape of the leaf and leaf tip of the vegetative "type" leaves. We have already discussed "ephemeral" leaves-these give no clue to the plant's identity. There are 3 kinds of vegetative leaves (a) un-lobed leaves, (b) asymmetric (odd sized, uneven lobing), and (c) symmetric (type) leaves. Leaf length can be extremely variable, depending on moisture. After one picks a group of leaves, discard the ephemeral leaves, the asymmetric leaves, and the unlobed leaves. The leaves remaining should fall into one of the leaf shapes in Figure 1. Figure 1(a) is the only exception to not using unlobed leaves for identification.

Key

A. Type leaves as in Fig. 1, (a) entire.

(1) Ephemeral leaves usually lobed. Plant 1-3-ft tall or taller, growing on the edge of salt-bush or low-sage ecotone. Never grazed. Usually found in the mixture of terrace sages below the high waterline of Lake Lahonton. 
Ephemeral leaves un-lobed, type leaf more pointed than in 1(a), not known to occur in Nevada.

Artemisia cana subspp. cana

B. Type leaves as in Fig. 1, (b). Thin, cruciform.

(2) Leaves 20-30 mm long. Plants 2- to 4 - $\mathrm{ft}$ tall. Mountains or foothills above $5500 \mathrm{ft}$ clevation. Never grazed. Artemisia tripartita subspp. tripartita

(3) Leaves about $3 \mathrm{~mm}$ long. Plant less than 1-ft tall. Growing on white gypsum outcrops. Low decumbent plant. Seldom grazed. Artemisia pygmaea Leaves 10-20 mm long, plant smaller than (2) above, usually heavily grazed. Not yet found in Nevada, but occurs in S. Oregon. Artemisia tripartita subspp. rupicola

(4) Leaves 4-8 mm long. Plants less than 1.ft tall, growing in alkaline areas, associated with shadscale (Atriplex confertifolia). Leaves bright green in February-March, yellow flower. Leaves dehiscent after spring growth, leaving spines on branches readily visible. Artemisia spinescens

C. Type leaves as in Fig. 1, (c). Straight-across tip, shallow notched lobes.

(5) Leaves 15-20 mm long. Plant 2- to 5-ft tall. Heads a fascicle of numerous branches, seeds small. Seed stalks light brown, persistent through winter. Found in good sites on deep soils. Rare. Artemisia tridentata subspp. tridentata

(6) Leaves 10-20 mm long. Plants 2- to 4-ft tall. Occupies terrace slopes and benches below $5000 \mathrm{ft}$. Heads vary from a single 2-inch spike in drought years to a thick-branched sheaf in wet years. Bark usually black, but new growth of uncrowded plants has light brown bark. Sometimes grazed by deer. Resistant to 2,4-D. Winward (1970) suggests Artemisia tridentata subspp. vaseyana form xericensis.)

D. Type leaves as in Fig. 1, (d). Central lobe exerted.

(7) Leaves $10-20 \mathrm{~mm}$ long. Plants 1-4-ft tall. Seed heads at maturity recurved, drooping at tip. Heads usually persist through winter, holding recurved tip. Never grazed. Occupies terrace slopes and benches below $5500 \mathrm{ft}$. Artemisia tridentata subspp. tridentata form parishii

(8) Leaves 10-30 mm long. Plants 3- to 8-ft tall. Occupies deep soils along draws. Heads seldom recurve. Plant may be important locally for dove nesting and quail roosting. Never grazed. Undoubtedly closely related to (7) above, mentioned because its seed heads almost never recurve.

Artemisia tridentata subspp. tridentata form parishii (tall draw)

E. Type leaves as in Fig. 1, (e). Wide graceful lobes, quickly narrowing to a thin pedicel.

(9) Type leaves 10-20 mm long. Plants 1- to 4-ft tall. Occupies terraces in mixed stands, found along some draws on mountains in pure stands. Highly palatable to deer. Choice fall diet for sagegrouse. Volunteers into wildfire burns readily. Unnamed Artemisia tridentata (widelobe). (Dr. Beetle feels this may be an ecotype of $A$. tridentata subspp. wyomingensis. I concur.)

F. Type leaves as in Fig. 1, (f). Deltoid leaf, central lobe too wide for central slot if deep lobed, has "buck-toothed" appearance when viewed above (end). Leaves silvery color. Type leaves 5-10 mm long.

(10) Plants 1- to 2-ft tall, heads in spikes with large seeds (4X the size of $A$. arbuscula or $A$. nova) appearing in the spring. Leaves, when crushed, have strong odor reminiscent of camphor (in spring) or hydraulic fluid (in fall). In nearly pure stands, shallow rocky soils; mixed with other sages on deep soils. Not grazed. Seldom eaten by sagegrouse, may cause strong odor to meat. Artemisia longiloba

(11) Plants 1-3-ft tall, heads in panicles, small-sized seeds appearing in summer. Leaves, when crushed, have sweet sage odor. Likes red-rock surfaces on deep soils, also grows in terrace sage complex. As palatable as bitterbrush (Purshia tridentata). Often found as a heavily grazed plant 2- to 6-inches tall.

Artemisia tridentata subspp. wyomingensis

G. Type leaves as in Fig. 1, (g). Well lobed, thick bodies.

(12) Type leaves 10-30 mm long. Symmetrical leaves rare. Plants 1-4-ft tall. Found on mountains above $5500 \mathrm{ft}$ associated with bitterbrush or pinyon pine. Heads a spike, very short pedicles on lateral branches, entire bracts along seed spike. Almost never grazed. In southern Nevada, lobes are notched rather than round lobcd. Very wide variety in this plant in size and appearance. If a big sage is growing above $5500 \mathrm{ft}$, it is almost always this subsp.

(13) Type leaves 2-5 mm long. Plant decumbent, low, usually less than 1-ft tall. Plant growing on lime hardpan or high lime soil. Leaves with tiny black glands under $10 \times$ glass. Seed heads brown, persistent. May be heavily grazed if gray-green color or ungrazed if glossy-green color. Leaves sticky to touch or when mashed between fingers. Artemisia nova

${ }^{4}$ Neither A.-cana subspp. bolanderi nor A. cana subspp. viscidula are known to occur in Nevada. See Beetle (1960) for description.

${ }^{5}$ Larger plant, leaves $20-40 \mathrm{~mm}$ long. Not known in Nevada. Artemisia tridentata subspp. vaseyana form spiciformis. 
(14) Type leaves 2-5 mm long. Low decumbent plant, usually less than 1-ft tall. Plant growing on neutral or acid soil (volcanic). Leaves may have white glands under $10 \times$ glass. May be heavily grazed if gray-green (silvery) color, or lightly grazed if green color. Artemisia arbuscula subspp. arbuscula (silvery), Artemisia arbuscula (unnamed green form).

The author has found certain plants with type leaves of both "blackbark" and Artemisia tridentata subspp. tridentata form parishii on the same plant, but this is exceptional. This list does not purport to be complete, but only to cover the more abundant sagebrushes found in Nevada. Several other unnamed sagebrushes have been found, but these are of minor importance.

When and if this work is verified by a competent scientist, an adequate taxonomist should describe those plants verified.

\section{Chromatographic Key ${ }^{6}$}

Primary flare-blue.

Sequence-blue (very large), dark green, fluorescent green, dark grcen blue, red, blue, dark green, blue, dark green Artemisia tridentata subspp. tridentata blue, red-brown, dark green, fluorescent green, dark green Artemisia tridentata (blackbark) Artemisia tridentata subspp. tridentata form parishii

blue, red, blue, dark green, blue, dark green Artemisia tridentata subspp. wyomingensis and Artemisia tridentata (widelobe) blue, red, dark green, green, dark green Artemisia tridentata (no lobe) blue, fluorescent green, dark green, green, dark green Artemisia longiloba

Primary flare-purple.

Sequence-purple, green, dark green, green, dark green Artemisia nova

Primary flare-red.

Sequence-red, dark green, light green, dark green Artemisia spinescens

Primary flare-orange.

Sequence-orange, blue green, dark green, blue, dark green Artemisia tridentata subspp. vaseyana and Artemisia tridentata subspp. vaseyana form spiciformis

Primary flare-yellow.

Sequence-yellow, red line, dark green, light green, dark green yellow, fluorescent green, dark green, light green, dark green Artemisia tripartita subspp. tripartita Artemisia arbuscula subspp. arbuscula and Artemisia arbuscula (green form)

${ }^{6}$ Ignore Chlorophyll flare.

\section{Literature Cited}

Beetle, Alan. 1960. A Study of Sagebrush. Wyo. Agr. Exp. Sta. Bull. $368.83 \mathrm{p}$.

Beetle, Alan A., and Alvin Young. 1967. A third subspecies in the Artemisia tridentata complex. Rhodora 67:405-406.

Hanks, Donald L., James R. Brunner, Donald R. Christensen, and A. Perry Plummer. 1971. Paper chromatography for determining palatability differences in various strains of big sagebrush. U. S. Dep. Agr., Forest Serv., Intermountain Forest and Range Exp. Sta., U.S.D.A. Forest Serv. Res. pap. INT 101. 9 p. Holbo, H. R., and H. N. Mozingo. 1965. The chromatographic characterization of Artemisia, section Tridentatae. Amer. J. Bot. 52:971978.
Plummer, A. Perry, Donald R. GhrisTENSEN, AND STEPhen B. Monsen. 1968. Restoring big-game range in Utah. Utah Div. of Fish and Game, Pub. No. 68-3 183 p.

Powell, JefF. 1968. Site factor relationship with volatile oils in big sagebrush. Thesis, Colo. State Univ. $58 \mathrm{p}$.

RANDERATH, KURT. 1966. Thin-layer chromatography. Verlag Chemie, Academic Press. 285 p.

Research Specialties. (undated) Operating manual OP-118-E, thin-layer chromatography. (Research Specialties Co.) $21 \mathrm{p}$.

Russeld, I. C. 1885. Geologic history of Lake Lahonton. U.S.G.S. Govt. Print. Office. $150 \mathrm{p}$.

Ward, Geo. H. 1953. Artemisia, section Seriphidium, in North America: A cytotaxonomic study. Contrib. from the Dudley Herbarium 4:115205.

Winward, A. H. 1970. Taxonomy and ecology of big sagebrush. Ph.D. Thesis Univ. of Idaho.

Winward, A. H., and E. W. Tisdale. 1969. A simplified chemical method for sagebrush identification. Idaho For., Wildlife and Range Exp. Sta. Note 11. $2 \mathrm{p}$.

Young, A. I. 1965. A chemical study of the taxonomy of section Tridentatae of the genus Artemisia. Wyo. Range Manage. Issue No. 198:2-12.

\section{CLYDE ROBIN NATIVE SEEDS} Castro Valley, California 94546 